\title{
Permanent 'phase shifts' or reversible declines in coral cover? Lack of recovery of two coral reefs in St. John, US Virgin Islands
}

\author{
Caroline S. Rogers ${ }^{1, *}$, Jeff Miller ${ }^{2}$ \\ ${ }^{1}$ US Geological Survey Caribbean Field Station, 1300 Cruz Bay Creek, St. John, US Virgin Islands 00830 \\ ${ }^{2}$ National Park Service, 1300 Cruz Bay Creek, St. John, US Virgin Islands 00830
}

\begin{abstract}
Caribbean coral reefs have changed dramatically in the last 3 to 4 decades, with significant loss of coral cover and increases in algae. Here we present trends in benthic cover from 1989 to 2003 at 2 reefs (Lameshur Reef and Newfound Reef) off St. John, US Virgin Islands (USVI). Coral cover has declined in the fore-reef zones at both sites, and no recovery is evident. At Lameshur Reef, Hurricane Hugo (1989) caused significant physical damage and loss of coral. We suggest that macroalgae rapidly colonized new substrate made available by this storm and have hindered or prevented growth of adult corals, as well as settlement and survival of new coral recruits. Overfishing of herbivorous fishes in the USVI and loss of shelter for these fishes because of major storms has presumably reduced the levels of herbivory that formerly controlled algal abundance. Coral cover declined at Newfound Reef from 1999 to 2000, most likely because of coral diseases. The trends that we have documented, loss of coral followed by no evidence of recovery, appear similar to findings from other studies in the Caribbean. We need to focus on functional shifts in the resilience of coral reefs that result in their inability to recover from natural and human-caused stressors.
\end{abstract}

KEY WORDS: Caribbean reefs · Recovery $\cdot$ Coral diseases $\cdot$ Hurricanes $\cdot$ Overfishing $\cdot$ Monitoring

Resale or republication not permitted without written consent of the publisher

\section{INTRODUCTION}

Recent syntheses have called attention to significant degradation of coral reefs in the Caribbean, particularly the loss of coral, increase in algae, loss of predatory fishes, and decreases in herbivorous urchins and fishes (Jackson et al. 2001, Gardner et al. 2003, Hughes et al. 2003, Pandolfi et al. 2003). Overfishing is often singled out as a primary cause, usually without an explanation as to exactly how intensive fishing is related to reef decline. Presumably, macroalgae increase in abundance because of the removal of herbivorous fishes, prevent settlement of coral recruits, and in extreme cases, overgrow adult coral colonies. Overfishing in combination with hurricanes has led to degradation of reefs, for example in Jamaica (Hughes et al. 1987, Hughes 1994). Corals have suffered partial and complete mortality from hurricanes, disease, bleaching, sedimentation, and boat/anchor damage (Wilkinson 2002).
It is not clear if the current community structure on some Caribbean coral reefs represents a permanent 'phase shift' or a reversible decline in coral cover and increase in algae. The concept of phase shifts or changes to alternate stable states on coral reefs first appeared in the 1980s (Lighty 1982, Hatcher 1984). Lighty (1982) described an 'alternate climax community' dominated by fleshy brown algae on Abaco Reef in the Bahamas and noted that radiocarbon dates from cores indicated little reef growth since $3500 \mathrm{yr}$, BP, on what was once an actively accreting reef. Two years later, Hatcher (1984, p. 199) described a macroalgal community that had replaced an area with live coral and algal turf, following the grounding of a vessel and release of pollutants on Myrimidon Reef, Great Barrier Reef. He noted that such shifts from the microalgae, or algal turf that then dominated most reef communities (see Dahl 1974) to an 'alternative stable state' with macroalgae had not been seen before under natural 
conditions. Later, in a comprehensive discussion of reef degradation, Done (1992) discussed 6 examples of phase shifts on reefs in Hawaii, Jamaica, Reunion, Moorea, and Australia. All involved extensive coral mortality followed by increases in algae.

The scientific literature now contains many references to phase shifts, usually referring to a change from coral 'dominance' to algal 'dominance,' but dominance has never been defined. Is a reef with $51 \%$ coral cover dominated by coral? Dominance is usually associated with occupation of space or 'cover,' i.e. a reflection of community structure rather than reef functional processes, such as growth and recruitment. If coral cover is $25 \%$ and increasing and algal cover is decreasing, however, one could argue that the corals are functionally dominant. Far more work has been done on reef structure and changes over time than on reef function or reef processes.

Many recent papers refer to phase shifts when referring not to well-defined, major shifts in benthic community composition but simply to decreases in coral cover and increases in algae (usually macroalgae). In other words, the phrase is applied generally to reefs that have lost coral cover rather than being restricted to those where substantial losses in coral cover and substantial increases in algal cover have been quantified, such as at Kaneohe Bay, Hawaii, and Discovery Bay, Jamaica.

Whether the shift takes place abruptly or over a long period, there is usually the implication that the phase shift will persist (e.g. Knowlton 1992). To date no one has documented a reversal of a phase shift back to initial coral cover and coral community composition on a Caribbean reef. Recovery is often thought of as an increase in coral cover, back to an (often unspecified) earlier level and time. However, as Done (1992, p. 128) notes, the most stringent definition of the point in time in which recovery can be considered complete, in ecological and geological terms, 'would be the restitution of prior diversity, mix of colony growth forms (if not species), colony size, frequency distributions, and structural extent and complexity of reef framework (after Johannes 1975)'.

Few long-term studies quantify changes on Caribbean reefs. Some of the longest continuous records of abundance (percent cover) of corals and other reef organisms in the Caribbean come from St. John, US Virgin Islands (USVI). Here we present trends in reef structure from Newfound and Lameshur Reefs, based on 12 to13 yr of monitoring using a traditional chain transect method and 4 to $5 \mathrm{yr}$ of monitoring with a new approach based on videotaping of randomly selected transects. We discuss the potential for recovery of these reefs, both of which have experienced declines in coral cover over the study period.

\section{MATERIALS AND METHODS}

Study areas. This paper describes research from 2 reefs off St. John, USVI (Fig. 1). Lameshur Reef is a fringing reef off Yawzi Point, which separates Great and Little Lameshur Bays on the south side of the island and falls within the boundary of Virgin Islands National Park (VINP). The reef extends seaward from a nearshore, shallow Acropora palmata zone to deeper water, where Montastraea annularis is the most abundant coral species. (Throughout this paper, we use the species name Montastraea annularis to refer to the $M$. annularis complex). The base of the reef occurs at about $15 \mathrm{~m}$, where there is a sand halo adjacent to an algal plain. The watershed is relatively undeveloped with a single residence and a small field station. There is no anchoring or commercial fishing allowed on the reef, although some fishing with traps and handlines takes place.

Newfound Reef is on the northeastern side of St. John, outside the boundary of the VINP. Although outside the national park, the watershed associated with this reef has no development. The reef crest is wider and better defined than at Lameshur Reef. It parallels the east and west shores of Newfound Bay and extends partway across the mouth of the bay from either direction, creating a shallow lagoon with a channel to the outer reef. Montastraea annularis is the most abundant species on the outer reef. The reef drops to about $14 \mathrm{~m}$, where it ends abruptly in a sand halo near an algal plain.

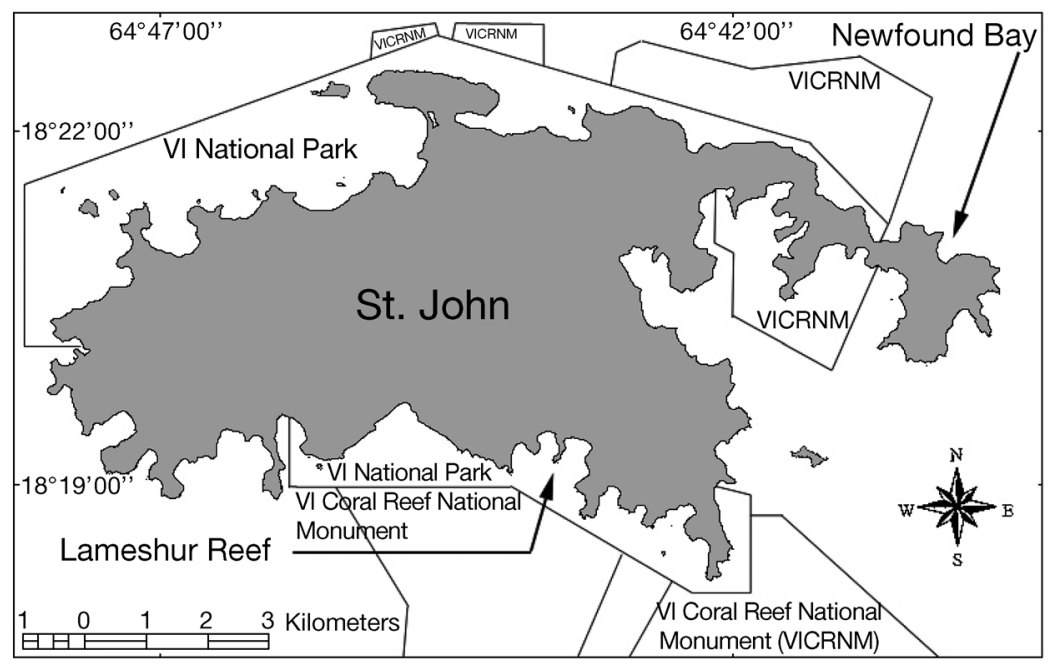

Fig. 1. Map of St. John, US Virgin Islands, showing the location of Lameshur and Newfound Reefs 
Survey methods. We used 2 different methods to quantify trends in cover by corals, macroalgae, and other benthic components in fore-reef zones at both reefs. Our approach to monitoring evolved over the last 15 years, becoming more rigorous as we acquired new technology and more people to conduct the work under the auspices of the National Park Service (NPS) and US Geological Survey (USGS) Inventory and Monitoring Program. At both sites, we initially used a linear chain transect method along haphazardly selected transects, but then augmented this in 1998 with videography along randomly chosen transects.

Chain transects: Initially, we used the linear chain transect method that has been used by the Caribbean Coastal Marine Productivity Program (CARICOMP) and many other reef-monitoring programs. It involves the positioning of a lightweight chain along the substrate under a measuring tape stretched between 2 survey stakes that define the ends of transects. The number of chain links of each benthic component is divided by the total number of links to give values for percent cover. In 1989, five $20 \mathrm{~m}$ transects were established at Lameshur Reef at depths of 10.7 to $12.7 \mathrm{~m}$. In 1990, a single $100 \mathrm{~m}$ transect (divided by survey stakes into ten $10 \mathrm{~m}$ sections) was installed at Newfound Reef at a depth of $7.6 \mathrm{~m}$. These transects were chosen because they represented sections of the fore-reef zones with high live coral cover, diversity, complexity, and structure. These transects will be referred to throughout this paper as the chain transects. They were surveyed once to twice a year at each reef, although only 1 sample per year was used in the statistical analyses. (For analysis of the Lameshur Reef data, 2 samples were used for 1989 to incorporate pre- and post-Hurricane Hugo values.)

From 1998 to 2002, videotapes were made along each of these chain transects (using the video protocol described below) at the same time as the chain transects were surveyed to compare results from the 2 methods along these non-randomly selected transects (see Rogers \& Miller 2001). The 2 methods provide similar results for coral cover, but macroalgae cover is higher with the video method. Details of this comparison will be presented elsewhere.

Video of randomly selected transects: From 1997 to 1999 we developed a method based on videotaping permanent transects that were randomly selected within the identified fore-reef zones. The videotaping creates a $10 \mathrm{~m}$ long by ca. $40 \mathrm{~cm}$ wide transect from which 25 to 30 non-overlapping images are captured, and 10 random points per image are applied $(=250$ to 300 points per transect). Benthic cover was estimated by identification (to the most specific level possible) of the substrate located under these random points.
Transects are filmed slowly (ca. $5 \mathrm{~min} / 10 \mathrm{~m}$ ) to enhance image clarity, with the camera perpendicular to and $40 \mathrm{~cm}$ above the bottom.

A protocol was developed for the random selection of sampling units (in this case, transects) at a study site. Traditionally, sampling units have been selected haphazardly or through the use of a number of fin kicks along random compass bearings from a previous sampling unit. We developed a new protocol based on the use of a sonar mapping system to locate positions underwater, ensuring random selection of transects without any observer bias. With this system, we could rapidly map the perimeter of the reef and define the sample population of potential transects (given defined spacing requirements, in this case $10 \mathrm{~m}$ ) and randomly select a number of sample points from within the total population of possible points. The coordinates of these points were then located and used as the origins of the transects. This protocol was used annually at 20, randomly chosen, $10 \mathrm{~m}$ transects at both Lameshur and Newfound Reefs from 1999 through 2003. Returning to the same transects each time, rather than re-randomizing, reduces variability and allows for a greater probability of detecting change (Rogers et al. 2002). Complete details of these protocols can be found at www1.nature.nps.gov/im/units/sfcn/ coral_reef_mon.htm.

At Lameshur Reef, the study zone had an area of $7125 \mathrm{~m}^{2}$ with a total sample population of 73 transects and ranged in depth from 13.7 to $15.0 \mathrm{~m}$. It was bordered by a sand halo/seagrass bed interface on 3 sides, and a sandy zone below a rock outcropping on the shallowest side (Fig. 2).

With an area of $13768 \mathrm{~m}^{2}$ and total sample population of 135 transects, the study zone at Newfound Reef ranged from 6.5 to $9.5 \mathrm{~m}$ and was defined by a sand channel to the south, a steep fore-reef slope to the east, a rocky headland outcropping to the north, and the reef crest to the west (Fig. 3).

Statistical methods: Chain transects and random video transects are revisited each sample period. Therefore, repeated measures analysis was conducted with JMP statistical software (SAS), using a mixed model approach and Tukey's Honestly Significant Difference (HSD) comparisons. Percent cover data were arcsin-transformed and evaluated for normality and homogeneity of variances prior to analysis. Where significant differences between category means were detected, actual p-values are provided. Linear regression was used to analyze the single $100 \mathrm{~m}$ chain transect at Newfound Bay. Regressions were also run for coral cover along permanent video transects at Newfound and Lameshur Reefs.

Stressors during the study period: During the study period (1989 to 2003), several hurricanes passed near the USVI, with Hurricane Hugo (1989) having the most 


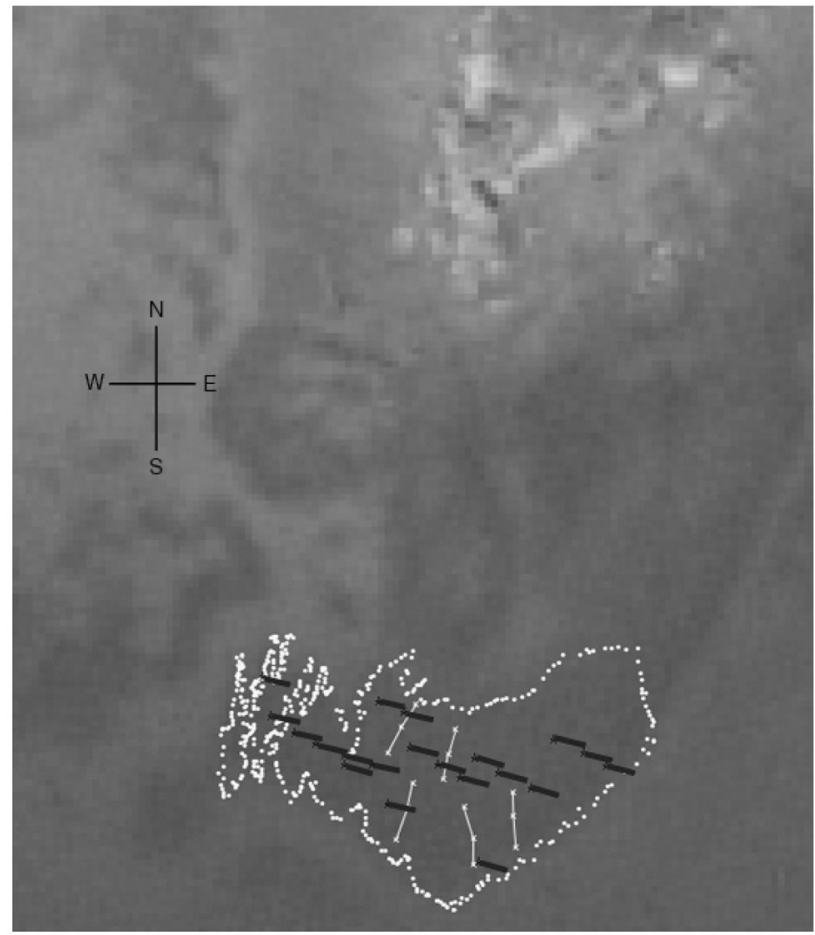

Fig. 2. Map of Lameshur Reef superimposed on a georeferenced aerial photograph. Locations of chain transects shown in white and permanent video transects in black

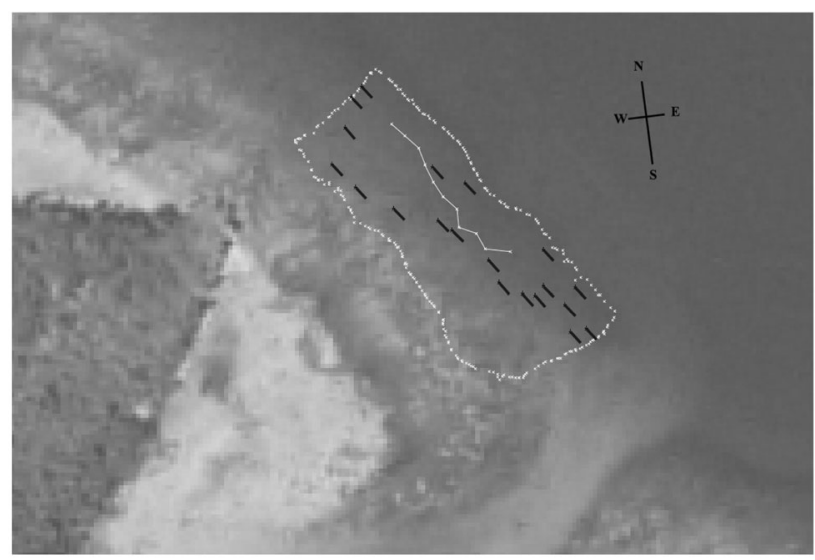

Fig. 3. Map of Newfound Reef superimposed on a georeferenced aerial photograph. Location of the single $100 \mathrm{~m}$ chain transect shown in white. Permanent video transects shown in black

significant effect on the coral reefs. Hurricane Hugo passed directly over St. Croix, $56 \mathrm{~km}$ south of St. John. The storm had an estimated maximum surface wind of $223 \mathrm{~km} \mathrm{~h}^{-1}$ and battered the islands for over $12 \mathrm{~h}$. In September 1998, Hurricane Georges came through the USVI, causing conspicuous damage to Newfound Reef. A severe bleaching episode began that September as well. Bleaching was evident along chain transects at both sites in 1998, but the reefs appeared to have recovered by 1999 (Rogers \& Miller 2001). The coral disease, white plague, has been observed frequently on both of the study reefs in the last $5 \mathrm{yr}$ (J. Miller pers. obs.).

\section{RESULTS}

\section{Video of 20 permanent random transects}

There were no significant differences in coral cover from 1999 to 2003 along randomly selected transects at Lameshur Reef. Both macroalgae and DCA (dead coral with algal turf) showed some differences among years, but no clear trends (Fig. 4, Table 1). At Newfound Reef, coral cover in 1999 was significantly higher than all other years $(\mathrm{p}<0.05)$. Coral cover decreased on all 20 transects from 1999 to 2000 and the mean coral cover declined from 18 to $14 \%$ (Fig. 5). Macroalgae and DCA varied among the years but no distinct trends were evident (Fig. 5, Table 1).
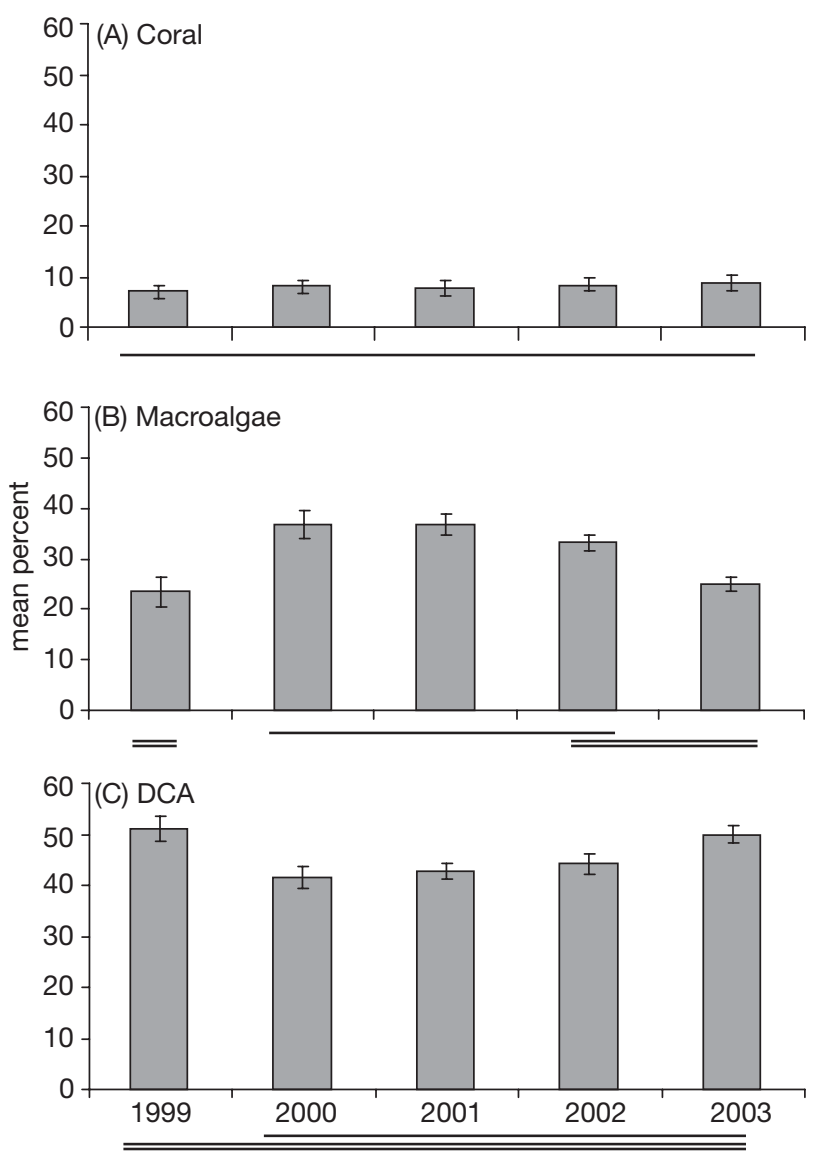

Fig. 4. Cover by (A) coral, (B) macroalgae, and (C) DCA (dead coral with algal turf) $\pm \mathrm{SE}$ along permanent random video transects at Lameshur Reef. Lines join means of years that are statistically similar $(\mathrm{p}<0.05)$ 
Table 1. Means, standard errors, and ranges of coral and algal cover at Newfound and Lameshur Reefs, USVI. For each sampling period, 20 random video transects were surveyed at Lameshur and Newfound. Five $20 \mathrm{~m}$ transects were surveyed at Lameshur, and one $100 \mathrm{~m}$ transect was surveyed at Newfound using the chain transect method. Video transects were conducted from 1999 to 2003; chain transects were conducted from 1989 to 2002 at Lameshur, and 1990 to 2002 at Newfound. DCA: dead coral with algal turf

\begin{tabular}{|c|c|c|c|c|c|c|}
\hline & \multicolumn{3}{|c|}{ Video along random transect } & \multicolumn{3}{|c|}{ Chain transects } \\
\hline & Mean (\%) & $\mathrm{SE}$ & Range (\%) & Mean (\%) & $\mathrm{SE}$ & Range (\%) \\
\hline \multicolumn{7}{|l|}{ Lameshur } \\
\hline Coral & 7.9 & 1.59 & $7.1-8.9$ & 11.6 & 0.55 & $8.3-22.5$ \\
\hline \multicolumn{7}{|c|}{ Montastraea annularis } \\
\hline$\%$ of substrate & 3.4 & 0.15 & $2.9-3.7$ & 4.8 & 0.38 & $3.4-9.3$ \\
\hline$\%$ of coral & 42 & 2.3 & $37.2-50.2$ & 40.1 & 0.91 & $35.4-48.2$ \\
\hline Macroalgae & 30.9 & 1.17 & $23.4-36.9$ & 18.3 & 1.3 & 1.9-33.5 \\
\hline DCA & 45.7 & 0.96 & $5.0-41.6$ & 43.3 & 1.3 & $31.1-64.9$ \\
\hline Macroalgae + DCA & 76.6 & 0.88 & $74.4-79.8$ & 61.6 & 0.98 & $39.4-70.5$ \\
\hline \multicolumn{7}{|l|}{ Newfound } \\
\hline Coral & 14.1 & 0.61 & $12.2-18.0$ & 23.2 & 0.54 & $20.8-26.2$ \\
\hline \multicolumn{7}{|c|}{ Montastraea annularis } \\
\hline$\%$ of substrate & 10.4 & 0.65 & $9.1-12.7$ & 15.6 & 0.45 & $13.5-18.3$ \\
\hline$\%$ of coral & 72 & 1.1 & $69.2-75.2$ & 67.7 & 0.64 & $64.9-71.2$ \\
\hline Macroalgae & 11.6 & 0.83 & $2.6-16.8$ & 6.3 & 0.76 & $2.0-10.7$ \\
\hline DCA & 42.7 & 0.81 & $39.4-50.3$ & 35.9 & 1.41 & $28.0-42.0$ \\
\hline Macroalgae + DCA & 54.3 & 0.88 & $49.6-60.3$ & 42.1 & 1.24 & $36.3-48.1$ \\
\hline
\end{tabular}
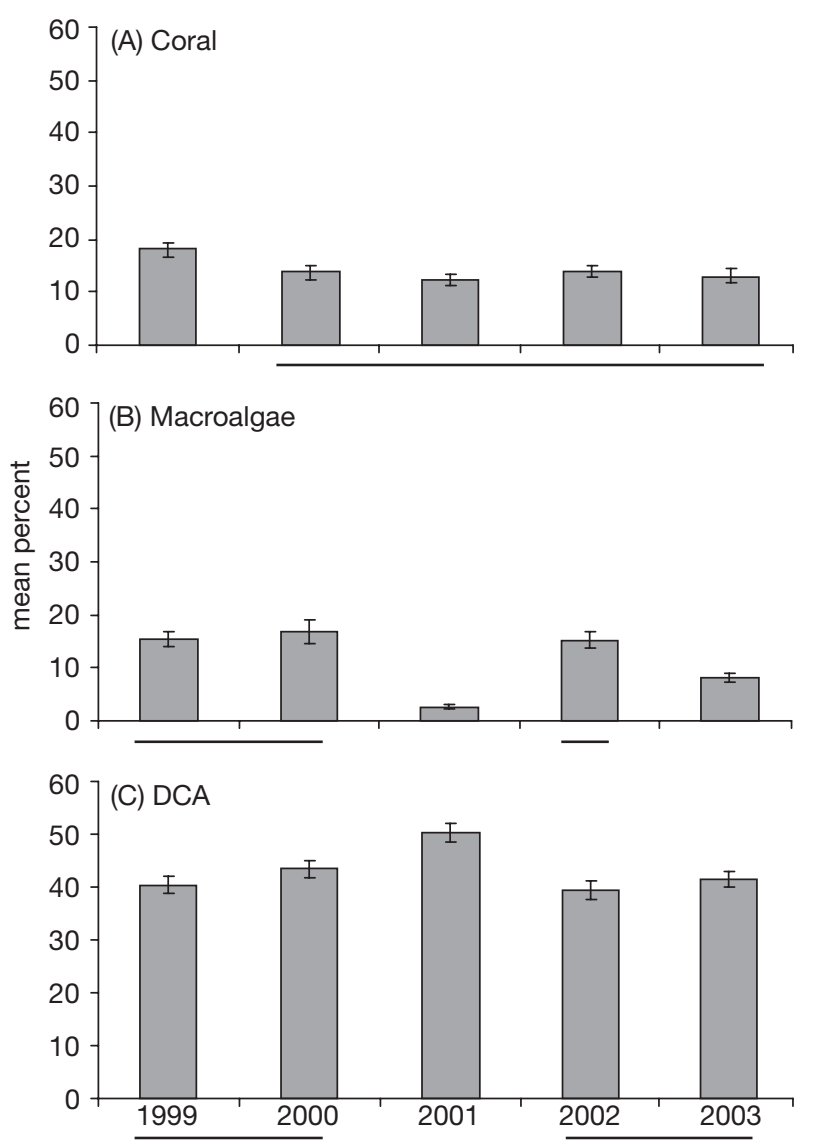

Fig. 5. Cover by (A) coral, (B) macroalgae, and (C) DCA (dead coral with algal turf) $\pm \mathrm{SE}$ along permanent random video transects at Newfound Reef. Lines join means of years that are statistically similar $(\mathrm{p}<0.05)$
Montastraea annularis was the most abundant coral at both study sites, comprising $72 \%$ of the total living coral at Newfound Reef and $42 \%$ at Lameshur Reef (Table 1). Other coral species had cover of less than $1.5 \%$ of the substrate and generally less than $10 \%$ of the total living coral cover. (There were 19 coral species along transects at both sites). Over the study period, Newfound Reef had higher mean coral cover and lower mean macroalgae and mean DCA cover than at Lameshur Reef. Cover by gorgonians and the sand/rubble/pavement category were higher at Newfound Reef (data not shown).

\section{Chain transects}

Hurricane Hugo (1989) caused a significant decline in total coral cover (from about 20 down to $12 \%$ ) and cover by Montastraea annularis (7.5 down to $5.2 \%$ of the substrate) along the five $20 \mathrm{~m}$ transects established at Lameshur Reef in 1989 (Fig. 6, Table 1; see also Rogers et al. 1997). Following the hurricane, coral cover has shown no evidence of increasing $\left(R^{2}=0.053\right.$, $\mathrm{p}=0.0553$ ). Macroalgae and DCA both varied greatly over the study period. Macroalgae (primarily Dictyota spp.) increased from $7.3 \%$ before Hurricane Hugo to $33.5 \%$ within a month after the storm. No effects of Hurricane Marilyn (September 1995) were noted.

There was a slight but significant increase in coral cover along the single $100 \mathrm{~m}$ transect surveyed from 1990 to 2002 at Newfound Reef $\left(R^{2}=0.406, p=0.0259\right)$ (Fig. 7, Table 1). Macroalgae and DCA showed no 

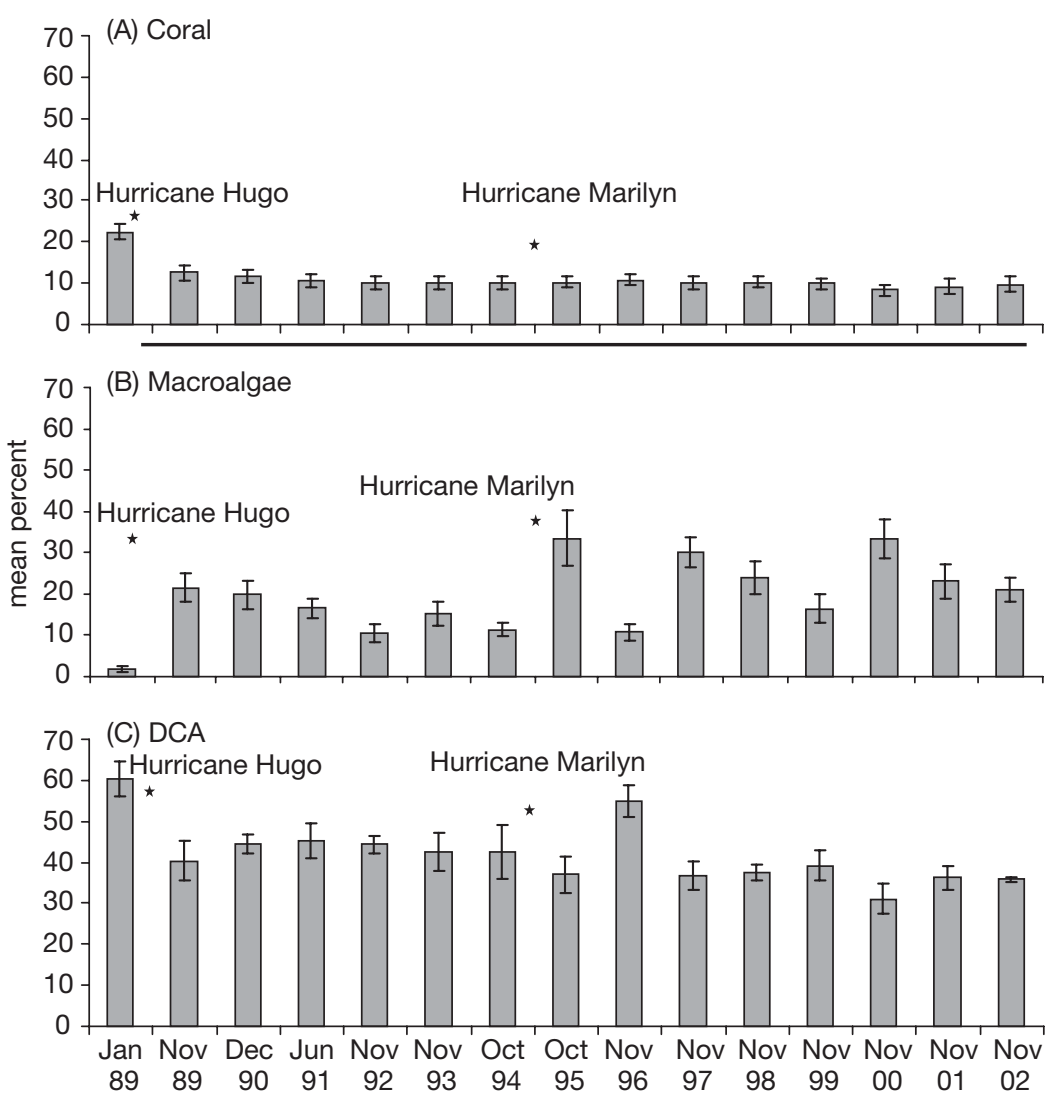

Fig. 6. Cover by (A) coral, (B) macroalgae, and (C) DCA (dead coral with algal turf) \pm SE along chain transects at Lameshur Reef. Lines join means of years that are statistically similar $(\mathrm{p}<0.05)$

significant trends. The mean percent coral cover was higher on the single transect at Newfound Reef and the 5 transects at Lameshur Reef than along the more widely distributed random video transects at each of these reefs for 1999 to 2002 (Figs. 4 to 7).

\section{DISCUSSION}

No evidence of recovery in terms of increases in coral cover or decreases in algal cover was found at either of our study sites, with the exception of a slight increase in coral cover along the single $100 \mathrm{~m}$ transect at Newfound Reef. A significant drop in total coral cover and cover by the most abundant coral species (Montastraea annularis along the chain transects at Lameshur Reef was caused by Hurricane Hugo (1989). Data from haphazardly selected linear chain transects showed trends in coral cover from 1999 to 2002 that were similar to those from randomly selected video transects at Lameshur Reef. Specifically, coral cover varied little at Lameshur Reef over those 4 yr, but at Newfound Reef, the coral cover along the $100 \mathrm{~m}$ transect increased slightly, while coral cover dropped significantly along the video transects. Significant decreases in coral cover may have been caused by disease primarily affecting M. annularis. Disease may have been less prevalent along the single chain transect than the more widely dispersed video transects, and the video technique is more effective in documenting visible changes such as bleaching or disease (Rogers \& Miller 2001). White plague has been seen on corals in the transects at both reefs and is causing significant mortality of several coral species around St. John, including M. annularis (J. Miller et al. 2003).

We suggest that the continued low coral cover and relatively high macroalgal cover at Lameshur Reef reflect the significant coral mortality from Hurricane Hugo, followed by colonization of newly available space by macroalgae, and a failure of the coral to recover because of low herbivory rates associated with intensive fishing of plant-eating fishes, particularly surgeonfishes and parrotfishes. One might expect that reefs would recover more quickly if coral mortality were caused by acute natural stressors such as hurricanes than by chronic stressors, because pre-stress conditions should return within a short period of time. However, the chronic stress of overfishing is most likely hindering or preventing recovery.

The abundance of herbivorous fishes also decreased directly as a result of Hurricane Hugo and returned to pre-storm (although already low) levels only after several weeks (Beets \& Rogers 2002, Beets \& Friedlander 2003). This decrease in herbivorous fishes was also seen in Jamaica after Hurricane Allen (Kaufman 1983). These storm-related decreases could result in more growth by macroalgae that colonize newly available substrate. Macroalgae overgrow crustose coralline algae that cement and stabilize the reef framework and also are known to facilitate settlement by at least some species of coral (Morse et al. 1988). Corals grow slowly, and the dominant species Montastraea annularis grows less than $1 \mathrm{~cm} \mathrm{yr}^{-1}$ (Hubbard \& Scaturo 1985), but we would have expected to see an increase in total live coral cover 15 yr after the 1989 hurricane. Edmunds (2002) has monitored 2 sites in Great Lameshur Bay (30 quadrats, along three $10 \mathrm{~m}$ transects per site), one at $9 \mathrm{~m}$ just east of our study site (which he calls 'Yawzi Point') and a deeper area $(14 \mathrm{~m})$ at Tektite Reef that is near the mouth of the bay. He found that Tektite, which was not damaged 

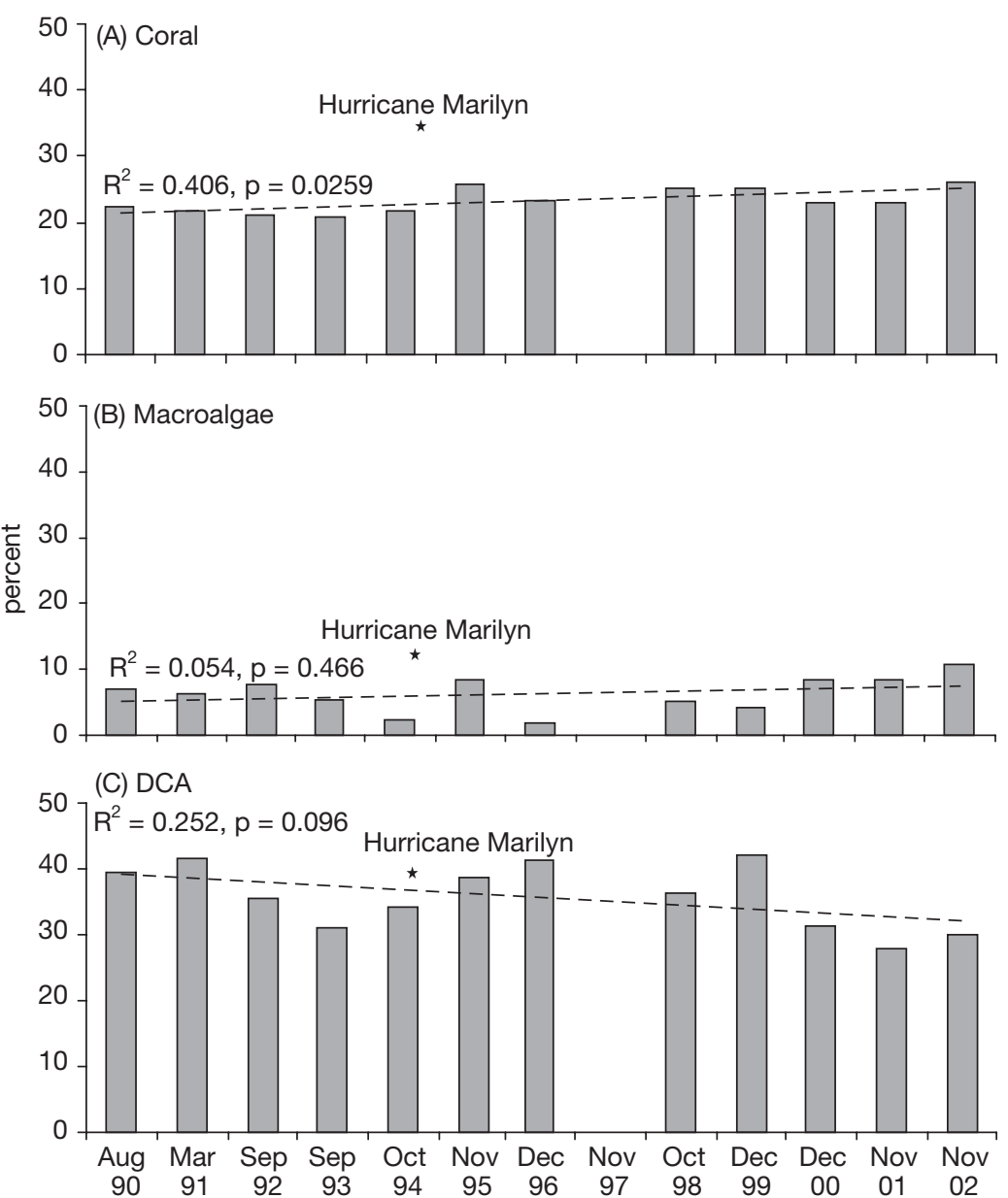

Fig. 7. Cover by (A) coral, (B) macroalgae, and (C) DCA (dead coral with algal turf) along the chain transect at Newfound Reef. Lines join means of years that are statistically similar $(p<0.05)$. Dashed lines represent linear regression fits

Although we suspect that coral disease played a role, we do not definitively know what caused the decrease in coral cover at Newfound Reef from 1999 to 2000, but recovery at this site could also be delayed or prevented by the decline in herbivory. When the 1999 and 2000 videotapes from this reef were examined side by side, using 2 monitors, total mortality of some coral colonies could be seen. We suggest that recovery at Newfound Reef is more likely than at Lameshur Reef because of the relatively low macroalgal cover and higher coral cover at Newfound Reef.

There is strong evidence that the reefs around the island of St. John have been overfished (Randall 1963, Beets 1997, Garrison et al. 1998, Rogers \& Beets 2001, Beets \& Rogers 2002). Trap fishing is allowed in Lameshur Bay, although it is inside the VINP, and fishing pressure is probably similar at Lameshur Reef and Newfound Reef. Beets \& Friedlander (2003) found that reef fish assemblages within VINP did not differ significantly from those outside the park boundaries. Declines in abundance of groupers and size of reef fishes have been observed in the USVI even within marine protected areas such as the VINP and Buck Island Reef National Monument, which were established over 40 yr ago (Rogers \& Beets 2001). Fish assemblages were probably

by Hurricane Hugo, had higher coral and lower macroalgal abundances than Yawzi Point, which showed declines in coral cover and cover by $M$. annularis similar to those we documented from the storm (Edmunds 2002). The storm damage to the physical structure of the reef following Hugo was conspicuous with many smashed and overturned coral colonies. However, damage was not reflected in a drop in spatial index along our permanent transects (possibly because some coral fragments were transported into the transects and because hurricane damage is 'patchy;' Rogers 1993). A decrease in the topographical complexity of the reef could lead to a decrease in habitat for herbivorous fishes and a reduction in herbivory (Szmant 1997). Bythell et al. (2000) suggest that herbivorous fishes were abundant enough to facilitate coral recruitment and prevent establishment of a macroalgal-dominated community on the south side of Buck Island, St. Croix, following successive hurricanes (Hugo, 1989, and Marilyn, 1995). altered well before these protected areas were established. Archaeological research on St. John at a Taino Indian site indicates that groupers and snappers became less common in the ceremonial offerings, and size of fishes became smaller, suggesting that even 1000 years ago, fishing was already having a significant effect (Quitmyer 2001, Wing \& Wing 2001). Later, during the plantation era of the 18th and early 19th centuries on St. John, reef fish, primarily parrotfishes, groupers, and snappers, were a significant part of the diet of enslaved Africans, representing up to $60 \%$ of the faunal remains at one site (Sichler 2003).

Will living coral increase on either of these reefs? A reversal in coral decline at Lameshur and Newfound Reefs would require active growth of adult colonies and successful recruitment and survival of new young colonies (primarily of Montastraea annularis). In the unlikely absence of additional human and natural stressors, such increases in coral cover could occur with increased herbivory by fishes (and, less likely, sea 
urchins), leading to the creation of suitable substrate for coral settlement and survival. The establishment of the Virgin Islands Coral Reef National Monument in 2001 (Fig. 1) with its prohibition on fishing could eventually lead to replenishment of herbivorous fish populations, but this marine reserve does not have boundaries based on ecological connectivity, and fishing is still allowed within the adjacent VINP.

Any increases in herbivory with continued increases in Diadema antillarum abundance could facilitate coral recruitment in shallow water, but are not likely to keep algal growth in check in moderate to deep water. Almost $20 \mathrm{yr}$ after the Caribbean-wide die-off of these sea urchins (Lessios 1988), D. antillarum are becoming more abundant in very shallow water in St. John, St. Croix (Cho \& Woodley 2002, R. J. Miller et al. 2003) and Jamaica (Edmunds \& Carpenter 2001), but they are not common in the deeper fore-reef zones at Newfound, Lameshur, or other reefs in the Caribbean (CARICOMP 2002). In surveys along random video transects in September 2004, fewer than 2 Diadema per transect were observed at Lameshur Reef, and in March 2005, only 3 urchins were seen along random transects at Newfound Reef (NPS unpubl. data). Even if herbivory increases, competition between corals and algae (especially macroalgae) could prevent recovery. Little is known about the interactions of macroalgae and corals (McCook et al. 2001), but some studies suggest that macroalgae (specifically Dictyota spp., which are abundant on many Caribbean reefs) may not only occupy space and hinder coral settlement, but may also release chemicals that could reduce coral growth and recruitment (Beach et al. 2003). Lirman (2001) documented loss of Montastraea faveolata tissue along coral/algal margins, but it is not clear what actually causes this mortality (D. Lirman pers. comm.). Threespot damselfishes Stegastes planifrons, which are very abundant on some Caribbean reefs, may be playing a role in preventing coral growth through maintenance of algae within their territories (Kaufman 1977). Abundance of macroalgae varies greatly, often over a period of just a few weeks and much more quickly than coral cover. Single, annual values for macroalgal cover need to be interpreted cautiously.

Although high macroalgal abundance is sometimes associated with high nutrient input, Szmant (2002) concluded that increases in nutrients are seldom the cause of major increases in algae on coral reefs (see also McCook 1999). Elevated nutrients are not responsible for the persistence of macroalgae on Newfound and Lameshur Reefs. Analysis of nutrients in the water column and in macroalgae collected from the study sites indicates low nutrient environments. Macroalgal samples (primarily Dicytota spp.) were collected monthly from November 1997 to January 1999 for analysis of nutrients (USGS unpubl. data). Macroalgal cover is consistently higher at Lameshur Reef than at Newfound Reef, and Lameshur Reef has higher percent $\mathrm{N}$ and lower $\mathrm{N}: \mathrm{P}$ ratios, but both sites have very low macroalgal tissue (primarily Dictyota) nutrients (mean $\mathrm{N}$ less than $1 \%$ and N:P ratios above 40 ) compared to Dictyota tissue nutrients from some reefs in the Florida Keys and Puerto Rico (e.g. Lapointe et al. 1992, Fong et al. 2001 and pers. comm). Water column nutrients collected every 1 to 3 mo over the last $10 \mathrm{yr}$ show similar concentrations for both sites, with mean values of nitrates less than $0.15 \mu \mathrm{M}$, nitrites less than $0.03 \mu \mathrm{M}$, ammonia less than $1 \mu \mathrm{M}$, and dissolved inorganic phosphates less than $0.08 \mu \mathrm{M}$ (USGS and NPS unpubl. data). These values indicate overall low nutrient environments compared to some sites in the Florida Keys, Puerto Rico, and Jamaica (Lapointe at al. 1992, Lapointe 1997, Fong et al. 2001).

The lack of coral recovery at Newfound and Lameshur Reefs probably reflects not a scarcity of coral recruits in the water column but rather the failure of successful settlement and survival of recruits. In a Caribbean-wide study of recruitment to terracotta tiles, Newfound Reef had some of the highest densities of coral spat within 9 mo of placement on the reef (R. Steneck pers. comm.). Edmunds (2000) found high spatial and temporal variability in density of juvenile corals on reef and non-carbonate substrates within Lameshur Bay, but density exceeded 50 per $0.25 \mathrm{~m}^{2}$ in some quadrats. As in other studies of coral recruitment in the Caribbean (Bak \& Engel 1979, Rogers et al. 1984, Rogers \& Garrison 2001), few recruits of the major reefbuilding corals, such as Montastraea annularis, were found.

While qualitative and quantitative data (including recent meta-analyses and syntheses by Gardner et al. 2003 and Pandolfi et al. 2003) point to irrefutable reef degradation in the Caribbean, comparison of reef community structure across the region and assessment of long-term trends are not as rigorous as one might hope. Our ability to evaluate the current status of Caribbean reefs rigorously is compromised by the lack of long-term research, particularly research based on random selection of sampling units (Lewis 2004). Reefs are heterogeneous ('patchy') on many scales, and selection of study sites and sampling units within study sites must be done in a way that provides confidence in our overall assessment of reef condition over the whole region. For example, around the small island of St. John $\left(52 \mathrm{~km}^{2}\right)$, coral cover in the fore-reef zones of 4 reefs that were monitored in 2003 ranged from $8.9 \%$ (Lameshur Reef) to $58.2 \%$ (Tektite Reef) (NPS unpubl. data). Both reefs are in Great Lameshur Bay and are separated by about $0.5 \mathrm{~km}$. This range in coral cover encompasses the values for 16 of the 21 CARICOMP 
sites distributed throughout the entire Caribbean (CARICOMP 2002). Even within a single reef zone, coral cover can vary widely.

The clearest, most accurate assessment of trends in Caribbean coral reefs will come from analysis of coral cover and macroalgal cover, reef fish assemblages, coral recruitment, and herbivory rates over several years at randomly selected transects stratified by reef zone and depth within reef zones. Although a few other studies have been based on random selection of study sites, we do not know of others besides the one described in this paper and others being conducted by the National Park Service in the USVI and Florida based on truly random selection of sampling units (transects, quadrats). We can certainly learn a great deal from studies based on sampling units that are not random, but it is important to acknowledge that they describe only changes on the transects and quadrats, not changes over the entire reef zone.

Many have noted the need for long-term research on coral reefs over a large geographic scale. CARICOMP provides valuable insights based on use of standardized methods in the same reef zones. However, neither the study sites nor the transects within them were selected randomly. It is precisely because there is so much spatial and temporal variation that it is critical to choose sampling sites randomly within reef zones of interest. The selection of the method to be used and the sampling design are not trivial, and conclusions drawn from analysis of reefs sampled with different methods, non-random quadrats or transects, over different periods of time (e.g. Gardner et al. 2003), should be viewed with caution.

Pandolfi et al. (2003) recently stated that USVI reefs are among the most degraded in the Caribbean. In contrast, we suggest that our study reefs are representative of many other sites in the region, where there have been losses of living coral from acute and chronic disturbances, followed by lack of significant recovery over several years.

Many people have mistakenly stated that Gardner et al. (2003) concluded that local, anthropogenic factors have been the primary cause of Caribbean-wide declines in coral cover. In fact, Gardner et al. (2003, p. 960) include disease and storms as 'local' stressors and differentiate these and anthropogenic stressors (like overfishing, sedimentation) from 'global stressors' such as 'temperature-induced bleaching.' Furthermore, the studies that Gardner et al. (2003) included in their meta-analysis were not studies of changes in coral cover from the same study sites from 1977 to 2001. Fewer than 20 studies were available for analysis until 1993. Finally, Gardner et al. (2003, p. 960) expressed 'guarded optimism' because of their finding of recent decrease in rates of coral cover decline in the USVI, something our data do not support.
Increases in coral cover have been reported from only a few sites in the Caribbean in Jamaica and Nicaragua, and these increases do not reflect increases in major reef-building species such as the Montastraea spp. and Acropora spp. (Edmunds \& Carpenter 2001, CARICOMP 2002, Cho \& Woodley 2002). An increase in the abundance of Diadema may be responsible for the observed increases in coral cover at shallow sites, but it is not clear why a few deeper sites $(10 \mathrm{~m}, 15 \mathrm{~m})$ with few or no urchins have higher coral cover and lower macroalgal cover, especially given that fishing pressure has not decreased.

We do not know what the coral cover was at Newfound and Lameshur Reefs 100 years ago, although it was probably much higher than it is now. It is not likely that coral cover will increase in the future, even though the recent establishment of the Virgin Islands Coral Reef National Monument with its prohibition on fishing (and anchoring) could lead to some re-bounding of herbivorous fish populations and concomitant increases in algal removal and successful coral recruitment and survival. Water quality is likely to decline with the continued rapid development of St. John, and the increasing Diadema populations are not likely to play a major role in deeper fore-reef zones. The increase in severity and prevalence of coral diseases, most notably white plague, represents yet another stress to already degraded coral reef ecosystems. The recent discovery that Halimeda acts as a reservoir for the pathogen that causes white plague is of particular concern (Nugues et al. 2004), given the abundance of macroalgae on the reefs of St. John, although Dictyota spp. are far more abundant than Halimeda.

In the last 20 years, macroalgae have certainly increased in biomass and cover on many coral reefs. However, this does not mean phase shifts have occurred. The term 'phase shift,' which has never been defined qualitatively or quantitatively, has been used frequently to describe not only major structural shifts from 'coral-dominated' to 'algal-dominated' states, but also more loosely to refer to any loss of coral cover that persists. True phase shifts require 'pulse' disturbances over large spatial scales (Done 1992, Knowlton 1992, Petraitis \& Latham 1999). Petraitis \& Dudgeon (2004) distinguish between assemblages that exist as alternate stable states under the same environmental conditions and those that characterize phase shifts, for example, from a coral-dominated to an algal-dominated assemblage, as a result of a change in the environment. Similarly, although they do not use the term 'phase shift', Beisner et al. (2003) describe 2 different perspectives on alternate stable states: one in which the environment is constant but shifts in variables occur ('community perspective') and the other in which environmental parameters change leading to a shift 
('ecosystem perspective'). When considering coral reefs, examples of variables that could shift over time would be coral cover, abundance or density, and environmental parameters could include the nutrient concentrations in the water or the amount of substrate available for colonization.

Aronson et al. (2004) use the terms phase shift and alternate stable states in describing changes that have taken place over decades to centuries in the most abundant coral species on reefs in Belize and Panama. They conclude that phase shifts occurred at both locations, with Agaricia tenuifolia replacing Acropora cervicornis in Belize and this same species replacing Porites spp. in Panama. They suggest the Belize reefs changed as a result of coral disease and represent an example of the 'community perspective' and the Panama reefs were altered because of deteriorating water quality and represent an example of the 'ecosystem perspective'.

The ability of a community to shift back to an earlier state is sometimes considered evidence of a phase shift rather than a characteristic of an alternate stable state. For example, Petraitis \& Dudgeon (2004, p. 352) imply that phase shifts are reversible and even small changes can lead to recovery of the initial state. However, they also state that: 'Assuming tropical reefs have a single equilibrium state in each environment one prediction seems clear: phase shifts to macroalgae states will remain and corals will not recover without environmental conditions being reversed.' Beisner et al. (2003) state that there would be evidence of alternate stable states if communities did not revert to their original state following the cessation of a perturbation. We suggest that because most reefs are 'perturbed' by several stressors, any effort to find evidence of a change from one alternate stable state to another because of a single stressor will be difficult. It is likely that the removal of individual stressors will not lead to a reversal in community structure. For example, even if all fishing is eliminated in a marine reserve, macroalgae may still persist on a reef and hinder coral recovery.

These recent and earlier interpretations of phase shifts and alternate stable states invite more discussion and debate. Clearly, if the distinction between phase shifts and alternate stable states is a useful one (and Petraitis \& Dudgeon [2004] think that the difference implies different management strategies and consequences), we would have to determine at what point a change in the environment had occurred and how long the new community would have to persist to represent a stable state. At what point would this state be considered irreversible? Beisner et al. (2003) ask if a statistical difference between abundances of organisms is sufficient for a state to be considered alternate.
Usually the term phase shift when associated with discussions of reef degradation refers to an increase in macroalgae and decrease in coral cover. Should the term also be used for cases where coral species have replaced other coral species, and is such a situation also a sign of reef degradation (see Aronson et al. 2004)? Should different phases be characterized only by organisms with very different characteristics, such as corals and algae, seaweeds and mussels (see Petraitis \& Dudgeon 2004)? In other words, we need to decide not only what is a 'shift' but what is a 'phase'. People disagree on whether small or large changes are required to shift communities from one alternate stable state to another. What constitutes a large and a small perturbation? We need to take into consideration that some stressors are inherently different in their effects on coral reefs, e.g. hurricanes destroy the physical structure of a reef whereas overfishing has indirect effects by removing herbivorous fishes that can promote coral recruitment by reducing macroalgal monopolization of the substrate.

Caribbean reefs are now subject to an unprecedented combination of natural and human-related stressors, and we need to focus on the 'shift' from reefs that can recover to reefs that cannot, and the contributing factors, rather than the relative abundance of the organisms that characterize the 'alternate' states. Coral reefs worldwide are being assaulted by an unprecedented combination of stresses that are natural and human-related, as well as by stresses like coral diseases that cannot yet be categorized as one or the other. Several different selfreinforcing processes or ecological 'ratchets' (Hughes 1994, Petraitis \& Latham 1999, Birkeland 2004) are now operating synergistically and simultaneously to jeopardize recovery.

Acknowledgements. The research described in this paper occurred over a span of $15 \mathrm{yr}$. During this time, several people worked for thousands of hours in the field and office to collect and analyze the data. We are especially grateful to R. Waara for his constant support of these projects over the last $10 \mathrm{yr}$. Special thanks to L. McLain, who was there at the very beginning. Others who helped a great deal include G. Beretta (who once fell asleep conducting the chain method), G. Garrison, L. Grober-Dunsmore, E. Link, A. Friedlander, N. Wolff, C. Tobias, B. Phillips, and S. Baker. C. Jeffrey helped immensely with the statistical analyses. J. Beets and A. Friedlander also assisted with the statistics. P. Fong helped us make sense out of our nutrient data and was very generous with her time. T. Done's thoughts on 'phase shifts' were instructive and entertaining. Thanks also to B. Precht for staying in touch and sending us helpful papers. We are grateful to B. Lidz for meticulous editing. Finally, we wish to thank C. Birkeland, I. Kuffner, R. Aronson, and an anonymous reviewer for their very constructive reviews of this manuscript. Any use of trade names is for descriptive purposes only and does not imply endorsement by the US Government. 


\section{LITERATURE CITED}

Aronson RB, Macintyre IG, Wapnick CM, O'Neill M W (2004) Phase shifts, alternative states, and the unprecedented convergence of two reef systems. Ecology 85:1876-1891

Bak RPM, Engel MS (1979) Distribution, abundance and survival of juvenile hermatypic corals (Scleractinia) and the importance of life history strategies in the parent coral community. Mar Biol 54:341-352

Beach K, Walters L, Borgeas H, Smith C, Coyer J, Vroom P (2003) The impact of Dictyota spp. on Halimeda populations of Conch Reef, Florida Keys. J Exp Mar Biol Ecol 297: 141-159

Beets J (1997) Can coral reef fish assemblages be sustained as fishing intensity increases? Proc 8th Int Coral Reef Symp 2: 2009-2014

Beets J, Friedlander A (2003) Temporal analysis of monitoring data on reef fish assemblages inside Virgin Islands National Park and around St. John, US Virgin Islands, 1988-2000. US Geological Survey Report

Beets J, Rogers C (2002) Changes in fishery resources and reef fish assemblages in a Marine Protected Area in the US Virgin Islands: the need for a no take marine reserve. Proc 9th Int Coral Reef Symp 1:449-454

Beisner BE, Haydon DT, Cuddington K (2003) Alternative stable states in ecology. Front Ecol Environ 1:376-382

Birkeland C (2004) Ratcheting down the coral reefs. BioScience 54:1021-1027

Bythell JC, Hillis-Starr ZM, Rogers CS (2000) Local variability but landscape stability in coral reef communities following repeated hurricane impacts. Mar Ecol Prog Ser 204: 93-100

CARICOMP (Caribbean Coastal Marine Productivity Program) (2002) Status and temporal trends at CARICOMP coral reef sites. Proc 9th Int Coral Reef Symp 1:325-330

Cho LL, Woodley JD (2002) Recovery of reefs at Discovery Bay, Jamaica and the role of Diadema antillarum. Proc 9th Int Coral Reef Symp 1:331-337

Dahl AL (1974) The structure and dynamics of algae in the coral reef ecosystem. Proc 2nd Int Coral Reef Symp 1: $21-25$

Done T (1992) Phase shifts in coral reef communities and their ecological significance. Hydrobiologia 247:121-132

Edmunds PJ (2000) Patterns in the distribution of juvenile corals and coral reef community structure in St. John, US Virgin Islands. Mar Ecol Prog Ser 202:113-124

Edmunds PJ (2002) Long-term dynamics of coral reefs in St. John, US Virgin Islands. Coral Reefs 21:357-367

Edmunds PJ, Carpenter RC (2001) Recovery of Diadema antillarum reduces macroalgal cover and increases abundance of juvenile corals on a Caribbean reef. Proc Natl Acad Sci 98:5067-5071

Fong P, Kamer K, Boyer KE, Boyle K (2001) Nutrient content of macroalgae with differing morphologies may indicate sources of nutrients for tropical marine systems. Mar Ecol Prog Ser 220:137-152

Gardner T, Cote IM, Gill JA, Grant A, Watkinson A (2003) Long-term region-wide declines in Caribbean corals. Science 301:958-960

Garrison VH, Rogers C, Beets J (1998) Of reef fishes, overfishing and in situ observations of fish traps in St. John, US Virgin Islands. Rev Biol Trop 46(Suppl 5):41-59

Hatcher BG (1984) A maritime accident provides evidence for alternate stable states in benthic communities on coral reefs. Coral Reefs 3:199-204

Hubbard DK, Scaturo D (1985) Growth rates of seven species of scleractinian corals from Cane Bay and Salt River, St.
Croix, USVI. Bull Mar Sci 36:325-338

Hughes TP (1994) Catastrophes, phase shifts, and large-scale degradation of a Caribbean coral reef. Science 265: $1547-1551$

Hughes TP, Reed DC, Boyle M (1987) Herbivory on coral reefs: community structure following mass mortalities of sea urchins. J Exp Mar Biol Ecol 113:39-59

Hughes TP, Baird AH, Bellwood DR, Card M and 13 others (2003) Climate change, human impacts, and the resilience of coral reefs. Science 301:929-933

Jackson JBC, Kirby MX, Berer WH, Bjorndal KA and 15 others (2001) Historical overfishing and the recent collapse of coastal ecosystems. Science 293:629-637

Johannes RE (1975) Pollution and degradation of coral reef communities. In: Ferguson-Wood EJ, Johannes RE (eds) Tropical marine pollution. Elsevier Oceanography Series 12. Elsevier Scientific Publ, New York, p 13-51

Kaufman LS (1977) The threespot damselfish: effects on benthic biota of Caribbean coral reefs. Proc 3rd Int Coral Reef Symp 1:559-564

Kaufman LS (1983) Effects of Hurricane Allen on reef fish assemblages near Discovery Bay, Jamaica. Coral Reefs 2: 43-47

Knowlton N (1992) Thresholds and multiple stable states in coral reef community dynamics. Am Zool 32:674-682

Lapointe BE (1997) Nutrient thresholds for bottom-up control of macroalgal blooms on coral reefs in Jamaica and southeast Florida. Limnol Oceanogr 42:1119-1131

Lapointe BE, Littler MM, Littler DS (1992) Nutrient availability to marine macroalgae in siliciclastic versus carbonaterich coastal waters. Estuaries 15:75-82

Lessios HA (1988) Mass mortality of Diadema antillarum in the Caribbean: What have we learned? Annu Rev Ecol Syst 19:371-393

Lewis J (2004) Has random sampling been neglected in coral reef faunal surveys? Coral Reefs 23:192-194

Lighty RG (1982) Fleshy-algal domination of a modern Bahamian Barrier reef: example of an alternate climax reef community. Proc 4th Int Coral Reef Symp 1:722

Lirman D (2001) Competition between macroalgae and corals: effects of herbivore exclusion and increased algal biomass on coral survivorship and growth. Coral Reefs 19: 392-399

McCook LJ (1999) Macroalgae, nutrients and phase shifts on coral reefs: scientific issues and management consequences for the Great Barrier Reef. Coral Reefs 18: 357-367

McCook LJ, Jompa J, Diaz-Pulido G (2001) Competition between corals and algae on coral reefs: a review of available evidence and mechanisms. Coral Reefs 19:400-417

Miller J, Rogers C, Waara R (2003) Monitoring the coral disease, plague type II, on coral reefs in St. John, US Virgin Islands. Rev Biol Trop 51:47-55

Miller RJ, Adams AJ, Ogden NB, Ogden JC, Ebersole JP (2003) Diadema antillarum 17 years after the mass mortality; is recovery beginning on St. Croix? Coral Reefs 22: 181-187

Morse D, Hooker N, Morse A, Jensen R (1988) Control of larval metamorphosis and recruitment in sympatric agariciid corals. J Exp Mar Biol Ecol 116:193-217

Nugues MM, Smith GW, van Hooidonk RJ, Seabra MI, Bak RPM (2004) Algal contact as a trigger for coral disease. Ecol Lett 7:919-923

Pandolfi JM, Bradbury RH, Sala E, Hughes TP and 8 others (2003) Global trajectories of the long-term decline of coral reef ecosystems. Science 301:955-958

Petraitis PS, Dudgeon SR (2004) Detection of alternative sta- 
ble states in marine communities. J Exp Mar Biol Ecol 300: 343-371

Petraitis PS, Latham RE (1999) The importance of scale in testing the origins of alternative community states. Ecology 80:429-442

Quitmyer I (2001) The zooarchaeology of Cinnamon Bay. National Park Service Report. US Dept of the Interior, Washington, DC

Randall JE (1963) An analysis of the fish populations of artificial and natural reefs in the West Indies. Caribb J Sci 3: $31-47$

Rogers C (1993) Hurricanes and coral reefs: the intermediate disturbance hypothesis revisited. Coral Reefs 12:127-137

Rogers CS, Beets JP (2001) Degradation of marine ecosystems and decline of fishery resources in marine protected areas in the US Virgin Islands. Environ Conserv 28:312-322

Rogers CS, Garrison G (2001) Ten years after the crime: lasting effects of damage from a cruise ship anchor on a coral reef in St. John. Bull Mar Sci 69:793-803

Rogers CS, Miller J (2001) Coral bleaching, hurricane damage, and benthic cover on coral reefs in St. John, US Virgin Islands: a comparison of results from the chain transect method and videography. Bull Mar Sci 69:459-470

Rogers CS, Fitz HC III, Gilnack M, Beets J, Hardin J (1984)

Editorial responsibility: Howard I. Browman (Associate Editor-in-Chief), Storebø, Norway
Scleractinian coral recruitment patterns at Salt River submarine canyon, St. Croix, USVI. Coral Reefs 3:69-76

Rogers C, Garrison V, Grober-Dunsmore R (1997) A fishy story about hurricanes and herbivory: seven years of research on a reef in St. John, US Virgin Islands. Proc 8th Int Coral Reef Symp:555-560

Rogers CS, Miller J, Waara R (2002) Tracking changes on a reef in the US Virgin Islands with videography and SONAR: a new approach. Proc 9th Int Coral Reef Symp 2: 1065-1071

Sichler J (2003) Historic period foodways in the Danish West Indies (1718-1917): the zooarchaeological evidence from Cinnamon Bay and the East End, St. John, Virgin Islands. $\mathrm{PhD}$ dissertation, University of Tennessee, Knoxville, TN

Szmant A (1997) Nutrient effects on coral reefs: a hypothesis on the importance of topographic and trophic complexity to reef nutrient dynamics. Proc 8th Int Coral Reef Symp 2: $1527-1532$

Szmant AM (2002) Nutrient enrichment on coral reefs: Is it a major cause of coral reef decline? Estuaries 25:743-766

Wilkinson C (ed) (2002) Status of coral reefs of the world: 2002. Australian Institute of Marine Science, Townsville

Wing SR, Wing ES (2001) Prehistoric fisheries in the Caribbean. Coral Reefs 20:1-8

Submitted: May 3, 2005; Accepted: August 23, 2005

Proofs received from author(s): December 12, 2005 